\title{
Short-circuit in the mangrove food chain
}

\author{
Marcus Sheaves ${ }^{1, *}$, Brett Molony $^{2}$ \\ ${ }^{1}$ Department of Marine Biology, James Cook University, Australia \\ ${ }^{2}$ W. A. Marine Research Laboratories, North Beach, Western Australia, Australia
}

\begin{abstract}
Crabs of the subfamily Sesarminae are important components of mangrove ecosystems in the Indo-west Pacific, Africa, the Caribbean and South America. By retaining a large proportion of mangrove leaf-litter within mangrove forests, they profoundly influence the functioning of mangrove ecosystems. Despite obvious importance to ecosystem functioning, little is known about predation on sesarmid crabs. Three large, predatory fishes of tropical lndo-Pacific estuaries, the groupers Epinephelus coioides and E. malabaricus and the snapper Lutjanus argentimaculatus are known to feed on brachyuran crabs. However, the contribution of sesarmids to the brachyuran component of the diets of these fishes is unknown. To determine the extent to which these fishes prey on sesarmid crabs, the gut contents and stable isotope values $\left(\delta^{13} \mathrm{C}\right.$ and $\left.\delta^{15} \mathrm{~N}\right)$ of $E$. coioides, E. malabaricus, and $L$. argentimaculatus from 3 mangrove estuary systems on the northeast coast of tropical Australia were investigated. All 3 species fed extensively on sesarmid crabs. Sesarmid crabs were the dominant food items for $E$. malabaricus and L. argentimaculatus, occurring in $50 \%$ of the stomachs that contained prey, and being the most common prey in terms of overall numbers. Although still the dominant prey, sesarmids occurred in only $30 \%$ of $E$. coioides stomachs. As well as being numerically dominant, sesarmids were large relative to other prey types. The 3 species also had stable isotope values enriched by about +0.75 to $+2 \delta^{13} \mathrm{C}$ and +1.5 to $+2.5 \delta^{15} \mathrm{~N}$, which were also consistent with extensive feeding on these crabs. Most other sympatric species had quite different diets and stable isotope profiles. Extensive feeding on sesarmid crabs by these fishes has a range of implications for the ecology of tropical mangrove ecosystems. Food webs are apparently more complex, and food chains leading from mangroves to top predators may be shorter than previously thought. Furthermore, a substantial part of the mangrove productivity sequestered by sesarmid crabs may be exported from mangrove ecosystems as a result of offshore migration by these fishes. The low incidence of piscivory in these fishes adds support to theories that reduced predation pressure may enhance the nursery ground value of tropical mangrove systems for fishes.
\end{abstract}

KEY WORDS: Food web · Mangroves · Sesarmid · Crab - Lutjanus - Epinephelus - Tropics · Estuary · Stable isotope

\section{INTRODUCTION}

Concepts of food webs and food chains have a long history (McIntosh 1985) and have generated much controversy (e.g. Cousins 1987, Polis 1991). Traditionally food webs have been treated as simple, with relatively few links per web and short ( 2 to 4 ) chain lengths (e.g. Briand 1983, Cohen et al. 1986). This simple model has provided much insight into the functioning of ecosystems. Recently, it has been argued that in

\footnotetext{
•E-mail: marcus.sheaves@jcu.edu.au
}

many cases this model is not adequate because food webs are much more complex, with many links and much longer (6 to 18) chains (Polis 1991). It is asserted that, to a large extent, the simple structure of early models reflected sampling artefacts and incomplete representations of communities both in terms of diversity and trophic connections (Briand 1983, Cohen et al. 1986, Polis 1991, Hall \& Raffaelli 1993). If so, many conclusions drawn from simple models are questionable (Menge et al. 1996, Winemiller \& Polis 1996). This has been countered by the argument that, despite complexity, general patterns in the abundance, biomass and productivity of broad categories of organisms do 
exist (Hairston \& Hairston 1997), so simple, general models are often informative. At present the extent to which generalizations apply is still unclear (Lawton 1999). Whether a simple or more complex model is necessary probably depends on the context of the study; the trade-off between simplicity and generality. and providing a detailed understanding of a particular system. However, even when a simple model is thought sufficient, complexity needs to be understood and its importance evaluated.

Working in Florida, Odum \& Heald (1975) described a mangrove food web dominated by detritus and detritivores. This was a reasonably simple system with the principal path of energy flow starting with mangrove leaf detritus, passing through saprophytic bacteria and fungi, to detritivores, lower carnivores and ultimately higher carnivores (Odum \& Heald 1975). It is now understood that intrinsically different biological processes operating in many mangrove systems mean that, for many parts of the world, this model must be modified. In mangrove systems in the Indo-Pacific a large proportion of mangrove leaf-litter is consumed or hidden underground by sesarmid crabs (Robertson et al. 1992). For instance, leaf-eating crabs remove between 25 and $80 \%$ of annual litter fall in mangrove forests in northeastern Australia, depending on forest type (Robertson \& Daniel 1989). Consequently, rather than being exported, much of the total mangrove productivity is retained within the system, where it can enhance primary productivity (Robertson 1991), and by increasing the availability of detritus within the sediments, support detritivore communities (Giddins et al. 1986). Thus, in the light of increased understanding of the importance of alternative pathways for the flow of energy and nutrients, it appears that mangrove food webs are often more complex than was once thought.

Although recognition of the pivotal role played by leaf-eating sesarmid crabs has led to an improved understanding of the complex nature and functioning of mangrove ecosystems, even this important component of the mangrove food web is not completely understood. For example, despite obvious importance to ecosystem functioning, little is known about predation on sesarmids. This situation exists for 3 reasons. Firstly, detailed dietary studies of predators in tropical mangrove systems are surprisingly rare. Secondly, sample sizes are usually small. Thirdly, where details of diet are available, the identity of crab components is rarely reported at a taxonomic level below 'Brachyura'. Some literature exists that suggests that sesarmids may be important in the diet of juvenile saltwater crocodiles Crocodylus porosus (Taylor 1979, Webb et al. 1991). However, compared to other potential crab predators such as fishes, crocodiles are uncommon, and so unlikely to play a major role in sesarmid predation.
Limited data are available for mangrove fishes. Grapsidae (the family that includes Sesarminae) is only a minor component of the diet of the barramundi Lates calcarifer (Davis 1985), the largest predatory fish common in Australian mangrove estuaries. On the other hand, Salini et al. (1990) reported that Brachyura contributed more than $50 \%$ by dry weight to the diets of 4 fishes; the serranid Epinephelus suillus (a synonym of E. coioides) $(\mathbf{n}=20)$, the carangid Gnathanodon speciosus $(\mathrm{n}=34)$, the lutjanid Lutjanus argentimaculatus ( $\mathrm{n}=11$ ), and the toxotid (archerfish) Toxotes chatareus ( $n=73$ ), from the Embley Estuary in tropical Australia. L. argentimaculatus, E. coioides, and another serranid, E. malabaricus, are common along mangrove-lined banks of tropical Australian mangrove systems (Sheaves 1992, 1996a). Because of this, and because sesarmids are the dominant crabs in Australian mangrove forests (Smith et al. 1989, Frusher et al. 1991, McIvor \& Smith III 1995), it is likely that a large part of the brachyuran component of the diet of these fishes may consist of sesarmids. This hypothesis is supported by Robertson $\&$ Duke (1990), who reported that sesarmids were common in the diet of the $L$. argentimaculatus $(\mathrm{n}=10)$.

Although only present as juveniles in tropical estuaries, Epinephelus coioides, E. malabaricus and Lutjanus argentimaculatus are large predators, reaching at least 500 to $700 \mathrm{~mm}$ fork length in these systems (Sheaves 1995), and not moving offshore until they are approximately 400 to $500 \mathrm{~mm}$ long. None of these species have been reported in the diets of Crocodylus porosus (Taylor 1979, Webb et al. 1991, Shahrul \& Stuebing 1996) or Lates calcarifer (Davis 1985), the only predators in these systems regularly reaching larger sizes than $E$. coioides, $E$. malabaricus and $L$. argentimaculatus. This suggests that these 3 species are not preyed upon extensively. So, although it is not entirely clear that they can be classified as top predators (small individuals are likely to be vulnerable to a number of predators), at least at larger sizes, E. coioides, E. malabaricus and L. argentimaculatus are close to the top of estuarine food webs.

If these common predators do feed extensively on sesarmid crabs, it may add another layer of complexity to mangrove food webs and have profound implications for the retention and recycling of nutrients within mangrove systems. By feeding directly on leaf-eating crabs, fish such as Epinephelus coioides, E. malabaricus and Lutjanus argentimaculatus may redirect part of the energy normally recycled by sesarmid crabs directly into upper levels of estuarine food webs.

In this study we investigate the extent to which Epinephelus coioides, E. malabaricus and Lutjanus argentimaculatus from 3 mangrove systems on the nor theast coast of tropical Australia prey on sesarmid crabs, and how closely these species are linked to mangrove productivity relative to sympatric species. 


\section{METHODS}

We utilized 3 estuaries on the northeastern coast of tropical Australia for our study sites: Gentle Annie Creek, Press's Pocket and the Hinchinbrook Channel (Fig. 1). These estuaries are lined by intertidal mangrove forests for most of their lengths. The mangrove forests comprise a variety of species, principally $R h i$ zophora stylosa, $R$. apiculata, $R$. mucronata, Ceriops australis, C. tagal, Bruguiera gymnorrhiza, B. parviflora, Xylocarpus granatum, X. mekongensis, Sonneratia alba, Aegialitis annulata, Aegiceras corniculatum and Avicennia marina.

We collected Epinephelus coioides, E. malabaricus and Lutjanus argentimaculatus between August 8 , 1994, and November 18, 1997, by angling with artificial lures. We chose this method of collection because netting methods are inefficient in sampling these species (Sheaves 1996b) and bait used in fish traps or on baited lines would complicate the interpretation of stomach contents. Other species of fish captured were retained for dietary comparison. The samples of other fish species were supplemented by fish captured on lines baited with peeled penaeid shrimp tails (i.e. with the exoskeleton removed) or strips of squid mantle. These 2 baits were chosen because neither contained hard parts that could lead to classification as anything but unidentifiable tissue. Samples were collected over the whole length of the estuaries and throughout the tidal cycle. The location within the creek and time of each capture were recorded. Captured fish were euthanased in an ice-seawater slurry and, as soon as possible after capture, the stomach and intestine were dissected out and fixed in a $10 \%$ formalin-seawater solution buffered with borax.

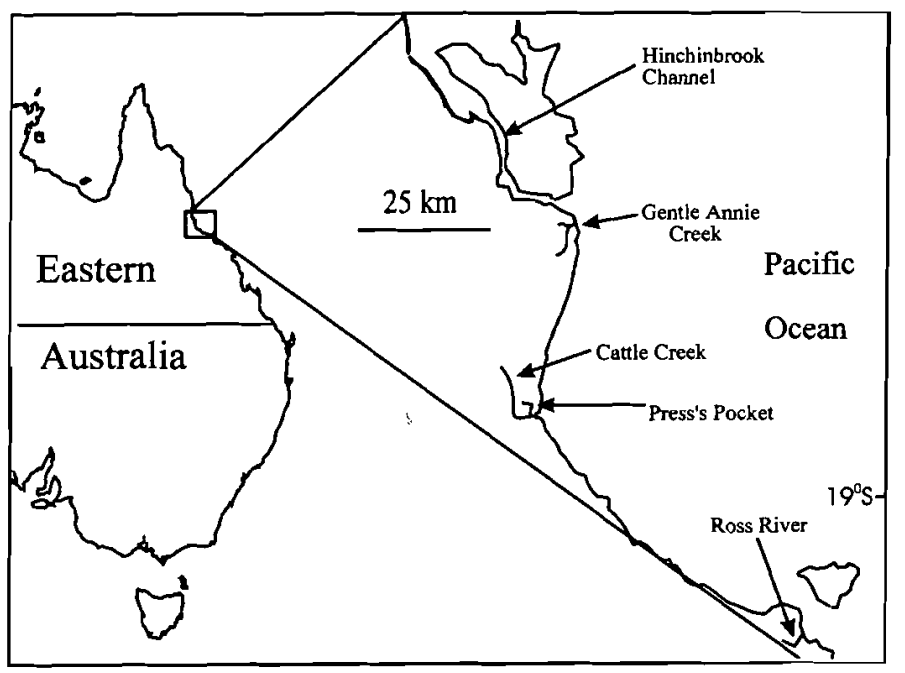

Fig. 1. Location of sampling sites on the northeastern coast of tropical Australia
We examined stomach and intestinal contents separately, and identified all items to the lowest taxonomic level possible. We measured all prey that were complete enough to provide reliable measurements: standard length (SL) for fish, maximum carapace width for crabs, and carapace length for shrimps. We recorded the weights of all prey items that appeared complete and undigested. We did not attempt volumetric analysis because a large proportion of items of prey were partially digested or fragmented.

A sample of 73 Perisesarma messa, the most common prey of the 3 main target fish species, was captured by hand and in pitfall traps from mangrove forests along the banks of Ross River (Fig. 1). We used linear regression (with a power transformation) to derive a total weight-carapace width relationship, in order to estimate weights of $P$. messa complete enough to measure, but too incomplete to provide reliable weights. The carapace width and weight of $P$. messa from stomachs were compared to the carapace width/weight data for crabs collected from Ross River. Because these data corresponded well, the width and weight data for other species of crabs from stomachs were used to produce regression estimates for the weight of individuals of those species too incomplete to weigh.

We modeled the presence/absence of sesarmid crabs, xanthid crabs, alpheid shrimps and fishes (the 4 most common prey) in the stomachs of Epinephelus coioides, E. malabaricus and Lutjanus argentimaculatus from the 3 mangrove systems using a linear logistic model (Collett 1991).

We analyzed the stomach contents (proportion of stomachs containing a prey category) of species represented by at least 10 individuals (Table 1) using nonmetric multidimensional scaling (NMDS) (Kruskal \& Wish 1978) with a Bray-Curtis dissimilarity measure. NMDS was used because it is essentially a non-parametric technique and so expected to be robust to non-linearity likely to be present in the data (Minchin 1987). We employed the BrayCurtis measure because only non-zero values are used in its calculation, so the presence of joint zeros does not influence the dissimilarity of observations (Clarke 1993). The results of the NMDS are presented as a biplot. Vectors representing the approximate direction of increase of the original variables in the reduced NMDS space were produced as follows. Each original variable (prey category) was regressed on the coordinates of points (fish species) on the reduced space axes using multiple regression. A vector projected from the origin of the reduced space plot to the coordinates defined by the partial regression coefficients for each reduced space axis then represented the direction of greatest 
Table 1. Summary of fish data used in stable isotope and gut content analyses. Main prey items listed for the present study are those present in at least $10 \%$ of stomachs. Where sample sizes for gut contents for this study were $<50$ the main prey types reported from the literature on northern Australian estuarine fish are included. $n=$ sample size. The diet category 'crabs' includes all Anomura and Brachyura except sesarmids

\begin{tabular}{|c|c|c|c|c|}
\hline Fish species & $\begin{array}{l}\text { Stable } \\
\text { isotope } \\
\text { (n) }\end{array}$ & $\begin{array}{c}\text { Gut } \\
\text { content } \\
\text { (n) }\end{array}$ & $\begin{array}{l}\text { Main prey } \\
\text { (this study) }\end{array}$ & Source \\
\hline Acanthopagrus australis & 4 & 93 & Bivalves $>$ gastropods & - \\
\hline Acanthopagrus berda & 5 & 249 & Bivalves $>$ gastropods $>$ polychaetes $>$ sesarn & mids \\
\hline Apogon hyalosoma & 2 & - & - & - \\
\hline Arius graefei & 2 & 2 & Penaeids & - \\
\hline Caranx ignobilis & 8 & 41 & Fish $>$ penaeids $=$ Acetes & Penaeids, fish ${ }^{a}$ \\
\hline Caranx sexfasciatus & - & 44 & Acetes $>$ fish & Penaeids, fish ${ }^{\mathrm{a}}$ \\
\hline Epinephelus coioides & 5 & 78 & Sesarmids $>$ crabs $>$ alpheids & - \\
\hline Epinephelus malabaricus & 5 & 134 & Sesarmids $>$ crabs & - \\
\hline Gerres filamentosus & 2 & 4 & Bivalves & - \\
\hline Hyporhamphus affinis & 2 & 2 & Algae & - \\
\hline Lutjanus argentimaculatus & 9 & 218 & Sesarmids $>$ fish $>$ alpheids & - \\
\hline Lutjanus russelli & 2 & 9 & Acetes $>$ penaeids & Penaeids, fish ${ }^{c}$ \\
\hline Monodactylus argenteus & 2 & 2 & Copepods $=$ fish eggs & Benthic invertebrates, plankton ${ }^{a}$ \\
\hline Pomadasys argenteus & 4 & 16 & Bivalves $=$ penaeids $>$ polychaetes & - \\
\hline Pomadasys kaakan & 2 & 95 & Bivalves $>$ crabs $>$ prawns $=$ polychaetes & Fish, crustaceans ${ }^{c}$ \\
\hline Platycephalus fuscus & 2 & 34 & Fish & Fish $^{\mathrm{a}}$ \\
\hline Sardinella albella & 2 & 2 & Copepods & - \\
\hline Scomberoides commersonnianus & 4 & 4 & Fish & Fish $^{c}$ \\
\hline Scomberoides lysan & 2 & 24 & fish $>$ Acetes & Fish $^{\mathrm{a}}$ : fish, Acetes ${ }^{\mathrm{b}}$ \\
\hline Sphyraena putnamiae & 2 & 4 & Fish & Fish $^{c}$ \\
\hline Sillago sihama & - & 10 & Bivalves & Penaeids, fish ${ }^{a}$ \\
\hline Terapon jabua & 2 & 2 & - & Penaeids ${ }^{\mathrm{a}}$ \\
\hline Toxotes chatareus & 3 & 3 & Sesarmids & Insects $^{\mathrm{a}}$ : crabs, plants ${ }^{\mathrm{c}}$ \\
\hline Ulua aurochs & 2 & 6 & Acetes $=$ fish & - \\
\hline
\end{tabular}

increase of each of the prey categories in the reduced space. To indicate how well prey categories were represented in the reduced space the lengths of the vectors were set proportional to the squared multiple correlation coefficient. Only prey categories with squared multiple correlation coefficients of $>0.3$ with the reduced space were plotted. The resulting NMDS showed 4 apparent groups of fish species. As an independent check on the integrity of these 4 groups a Kmeans clustering $(K=4)$ was conducted and the results of the clustering superimposed on the NMDS plot.

We collected sections of the dorsal musculature, forward of the first dorsal fin, of fish captured during January 1997 and July 1998 for stable isotope analysis $\left(\delta^{13} \mathrm{C}\right.$ and $\delta^{15} \mathrm{~N}$ ). In July 1998 we collected sesarmid crabs Perisesarma messa, alpheid shrimps Alpheus cf. malabaricus, and fallen mangrove leaves of Rhizophora stylosa and Avicennia marina from mangrove forests at Cattle Creek for stable isotope analysis. Fallen leaves from additional mangrove species and filamentous benthic algae were collected from the Hinchinbrook Channel. Muscle tissue from both fish and crustaceans was frozen before being freeze dried. Plant tissue was rinsed in distilled water before freeze drying.
Samples for stable isotope analysis were shipped to the University of Queensland's Botany Department, where isotopic analyses were conducted on a Europa Scientific Tracermass mass spectrometer (reproducibility of $0.2 \%$ for both carbon and nitrogen) with a Europa Scientific Roboprep preparation system. The isotopic ratios ${ }^{13} \mathrm{C} /{ }^{12} \mathrm{C}$ and ${ }^{15} \mathrm{~N} /{ }^{14} \mathrm{~N}$ for samples were determined and expressed as \%o differences from PDB standards and atmospheric $N$, respectively, to give $\delta^{13} \mathrm{C}$ and $\delta^{15} \mathrm{~N}$ stable isotope ratios.

\section{RESULTS}

We found some marked asymmetries in catches of our 3 main target species among the sampling locations. We caught Epinephelus coioides in relatively low numbers at all locations (Table 2) and primarily in seaward areas of the estuaries. In contrast, we caught E. malabaricus and Lutjanus argentimaculatus in similar numbers throughout the estuaries. This pattern had been reported previously from fish trap studies (Sheaves 1992, 1996b). Although we caught all 3 species at each location, we caught relatively few E. mal- 
Table 2. Summary of catches of Epinephelus coioides, E. malabaricus and Lutjanus argentimaculatus from 3 estuaries. FL $=$ fork length

\begin{tabular}{|c|c|c|c|}
\hline & Gentle Annie & $\begin{array}{c}\text { Estuaries } \\
\text { Hinchinbrook }\end{array}$ & Press's Pocket \\
\hline \multicolumn{4}{|l|}{ E. coioides } \\
\hline $\mathrm{n}$ & 32 & 26 & 20 \\
\hline Mean FL (mm) & 297 & 313 & 274 \\
\hline FL range (mm) & $210-395$ & $248-416$ & $155-395$ \\
\hline \multicolumn{4}{|l|}{ E. malabaricus } \\
\hline $\mathrm{n}$ & 59 & 52 & 23 \\
\hline Mean FL (mm) & 345 & 347 & 346 \\
\hline FL range $(\mathrm{mm})$ & $211-490$ & $201-495$ & $198-518$ \\
\hline \multicolumn{4}{|c|}{ L. argentimaculatus } \\
\hline n & 77 & 36 & 105 \\
\hline Mean FL (mm) & 332 & 307 & 344 \\
\hline FL range $(\mathrm{mm})$ & $170-440$ & $192-420$ & $176-445$ \\
\hline
\end{tabular}

cus 35 prey taxa and L. argentimaculatus 32 prey taxa. Diets of all 3 species were dominated by Brachyura, both in the number of individual prey items and the proportion of stomachs containing particular prey categories. The brachyuran subfamily Sesarminae was the dominant prey for E. malabaricus and L. argentimaculatus, occurring in $50 \%$ of stomachs with prey, including the smallest individuals of each species. Perisesarma messa was the dominant sesarmid, occurring in $25 \%$ of the $L$. argentimaculatus stomachs containing prey. Sesarmids were less dominant for $E$. coioides occurring in $32 \%$ of stomachs. The next most important brachyuran group, Xanthidae, occurred in $17 \%$ of $E$. coioides and $18 \%$ of E. malabaricus stomachs but only $5 \%$ of $L$. argentimaculatus stomachs. In contrast to Brachyura, fish were not common prey items of E. coioides and E. malabaricus at Press's Pocket and few L. argentimaculatus at Hinchinbrook Channel.

The gut contents of 78 Epinephelus coioides, $134 \mathrm{E}$. malabaricus and 218 Lutjanus argentimaculatus were examined. Data from intestines are not presented because they showed no substantial differences in composition from, and were much more fragmented and decomposed than, stomach contents. The stomachs of 41 E. coioides, 98 E. malabaricus and 126 L. argentimaculatus contained food (Table 3). The stomachs of $E$. coioides contained a total of 26 prey taxa, E. malabariabaricus but were found in $31 \%$ of $L$. argentimaculatus stomachs containing prey. Only gobiids (14) up to $79 \mathrm{~mm}$ SL and small Siganus lineatus (6 from 2 stomachs) up to $21 \mathrm{~mm}$ SL were represented by more than 3 identifiable individuals from $L$. argentimaculatus stomachs. Most fish prey were small. Of those complete enough to provide reasonable measurements ( $\mathrm{n}=$ 25 ), the mean SL was $36.7 \pm 4.9 \mathrm{~mm}$ and mean weight was $2.4 \pm 0.9 \mathrm{~g}$. Similarly, few penaeid shrimps were found in the stomachs of either species of Epinephelus but were present in $12 \%$ of the L. argentimaculatus

Table 3. Summary of stomach content of Epinephelus coioides, E. malabaricus and Lutjanus argentimaculatus. Data are total number of each prey category and percentage (\%) of stomachs containing each prey category. Only fish with stomach contents are included. All prey categories occurring in at least $5 \%$ of one species of fish are included. Higher taxonomic groups contain data for all associated lower taxa

\begin{tabular}{|c|c|c|c|c|c|}
\hline & & & $\begin{array}{l}\text { E. coioides } \\
(\mathrm{n}=41)\end{array}$ & $\begin{array}{l}\text { E. malabaricus } \\
\qquad(\mathrm{n}=98)\end{array}$ & $\begin{array}{l}\text { L. argentimaculatus } \\
\qquad(\mathrm{n}=126)\end{array}$ \\
\hline \multirow[t]{11}{*}{ Brachyura } & & & $54(85.4 \%)$ & $140(82.7 \%)$ & $111(63.5 \%)$ \\
\hline & Grapsidae & & $22(41.5 \%)$ & $86(57.1 \%)$ & $99(51.6 \%)$ \\
\hline & Sesarminae & & $16(31.7 \%)$ & $74(52.0 \%)$ & $92(50.0 \%)$ \\
\hline & & Sarmatium germaini & $0(0 \%)$ & $6(5.1 \%)$ & $19(15.1 \%)$ \\
\hline & & Perisesarma messa & $10(19.5 \%)$ & $30(19.4 \%)$ & $41(25.4 \%)$ \\
\hline & & $\begin{array}{l}\text { Perisesarma semperi } \\
\text { longicristatum }\end{array}$ & $2(4.9 \%)$ & $15(10.2 \%)$ & $12(7.1 \%)$ \\
\hline & & Neosesarma sp. & $0(0 \%)$ & $9(9.2 \%)$ & $7(3.2 \%)$ \\
\hline & Xanthidae & & $10(17.1 \%)$ & $23(18.4 \%)$ & $5(4.0 \%)$ \\
\hline & Pilumninae & Glabropilumnus cf. dispar & $4(7.3 \%)$ & $0(0 \%)$ & $0(0 \%)$ \\
\hline & Ocypodidae & & $6(12.2 \%)$ & $7(5.1 \%)$ & $0(0 \%)$ \\
\hline & Macrophthalminae & Leipcten trigranulum & $5(12.2 \%)$ & $5(5.1 \%)$ & $0(0 \%)$ \\
\hline \multirow[t]{3}{*}{ Caridea } & & & $10(24.4 \%)$ & $11(11.2 \%)$ & $33(22.2 \%)$ \\
\hline & Alpheidae & & $9(22.0 \%)$ & $9(8.2 \%)$ & $24(17.5 \%)$ \\
\hline & Palaemonidae & & $1(2.4 \%)$ & $2(2.0 \%)$ & $9(7.1 \%)$ \\
\hline Penaeoidea & Penaeidae & & $2(4.9 \%)$ & $6(4.1 \%)$ & $21(11.9 \%)$ \\
\hline \multirow[t]{2}{*}{ Perciformes } & & & $6(14.6 \%)$ & $7(6.1 \%)$ & $51(31.0 \%)$ \\
\hline & Gobiidae & & $0[0 \%)$ & $3(3.1 \%)$ & $11(7.1 \%)$ \\
\hline
\end{tabular}


stomachs containing prey. Alpheid shrimps (mainly represented by the major chela only) were also important, particularly for $E$. coioides and $L$. argentimaculatus.

Carapace width was an excellent predictor of weight (weight $=0.00020 \times$ width $^{3.3} ; \mathrm{r}^{2}=0.996$ ) for 73 Perisesarma messa captured from Ross River mangroves. The data for the $24 P$. messa from stomachs that were complete enough to provide useful weights fitted this relationship well. Although there was a tendency for weights to be slightly lower than for crabs collected fresh from Ross River, the difference was not substantial $(F=1.401, \mathrm{df}=2 / 94, \mathrm{p}=0.2516)$. Because $P$. messa removed in good condition from stomachs provided a reasonable approximation to the weights of freshcaught individuals, it was considered that carapaceweight relationships derived from crabs of other species taken from the stomachs of fishes would provide a reasonable approximation to the true relationships. For most species the relationship was similar to that for $P$. messa. However, the sesarmid genus Sarmatium (weight $=0.0012 \times$ width $^{2.9}$ ) and family Xanthidae (weight $=0.00070 \times$ width $^{2.9}$ ) required separate regressions.

When the distribution of carapace widths for sesarmids and xanthids from stomachs are converted to approximate weights it is clear that the great majority of xanthids (mean $\pm \mathrm{SE}, 2.04 \pm 0.735$ ) were very small compared to sesarmids (mean $\pm \mathrm{SE}, 4.79 \pm 0.314$ ). Thus, as well as dominating the diets of Epinephelus coioides, E. malabaricus and Lutjanus argentimaculatus numerically, sesarmids dominated the brachyuran component of the diet of all 3 species in terms of biomass. Furthermore, although there were some changes in the proportion of fishes of different weights utilizing various prey types, for $L$. argentimaculatus and E. malabaricus sesarmids were the major dietary component throughout the size range (Fig. 2).

The final logistic model for the presence/absence of sesarmids, xanthids, alpheids and fishes in the guts of Epinephelus coioides, E. malabaricus and Lutjanus argentimaculatus included an interaction between prey type and fish species and an independent effect of location (Fig. 3). The major differences in the diets of the 3 species were a low probability of occurrence of sesarmids in $E$. coioides and a high probability of occurrence of fish in $L$. argentimaculatus. The effect of location was due to a relatively low probability of finding any of the prey categories in fish from Press's Pocket.

A large proportion of fish had empty stomachs shortly after high tide (Fig. 4a). This proportion decreased over the 4 hours following high tide, then increased around the bottom of the tide (Hours 5 and 6) and early flood tide (Hour 7), stabilizing during later parts of the flood tide. The number of sesarmids in-

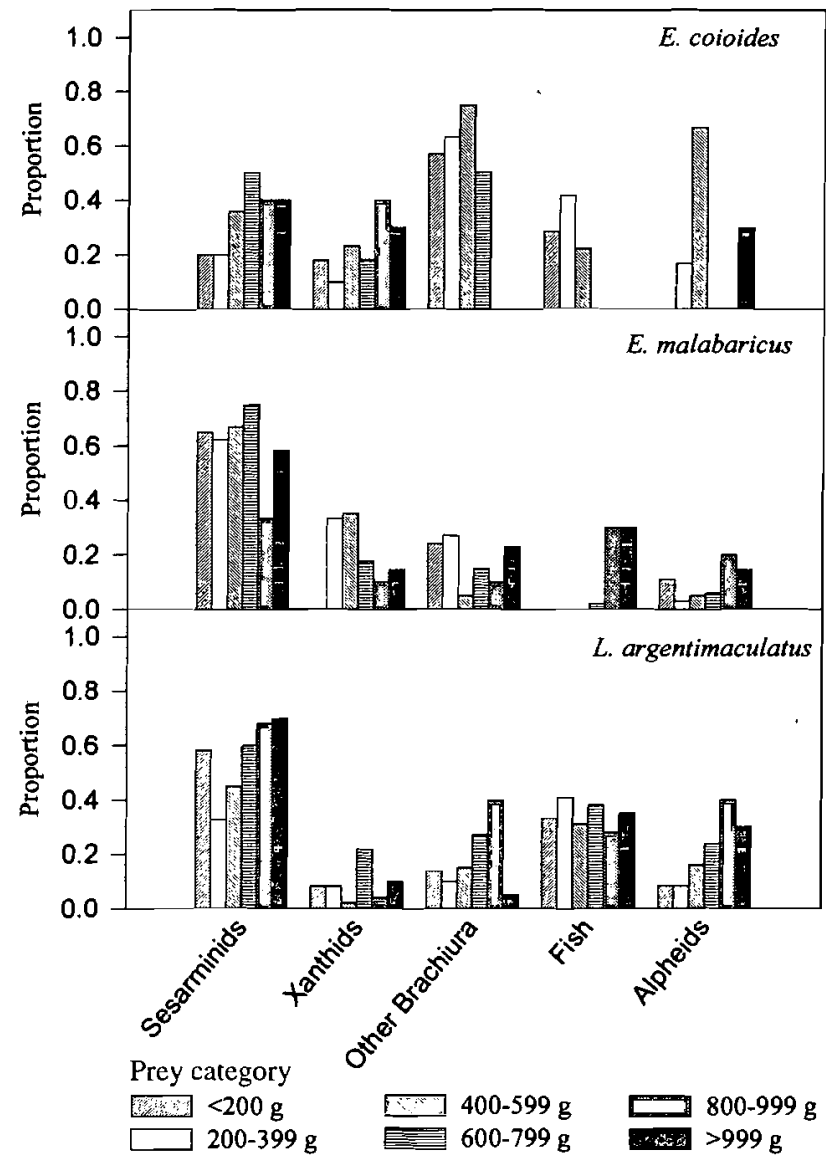

Fig. 2. Proportion of fish of different weights containing various prey categories

creased from high tide to some 4 hours after high (Fig. 4b), then fell away and remained low throughout the rest of the tidal cycle. The total number of prey also increased during the ebb tide, mainly due to the increase in sesarmid numbers. Factoring out the change in sesarmid numbers, the total number of prey remained similar throughout the tidal cycle.

The diets of Epinephelus coioides, E. malabaricus and Lutjanus argentimaculatus were similar, and quite distinct from the other 9 species analyzed by NMDS (Fig. 5). The diets of these 3 species were characterized by high proportions of crabs, primarily sesarmid crabs, and alpheid shrimps. Of the 12 species of fish analyzed using NMDS the only other species to include a substantial (but much smaller) proportion of sesarmid crabs in its diet was the sparid Acanthopagrus berda. Of the 11 species not included in the NMDS because of small sample size only Toxotes chatareus fed on, or was reported to feed on, sesarmid crabs (Table 1). The NMDS, supported by K-means clustering (Fig. 5), indicated 3 other dietary groups. The sparids Acanthopagrus australis and $A$. berda, the haemulids Pomadasys argenteus and P. kaakan, and the sillaginid Sillago 


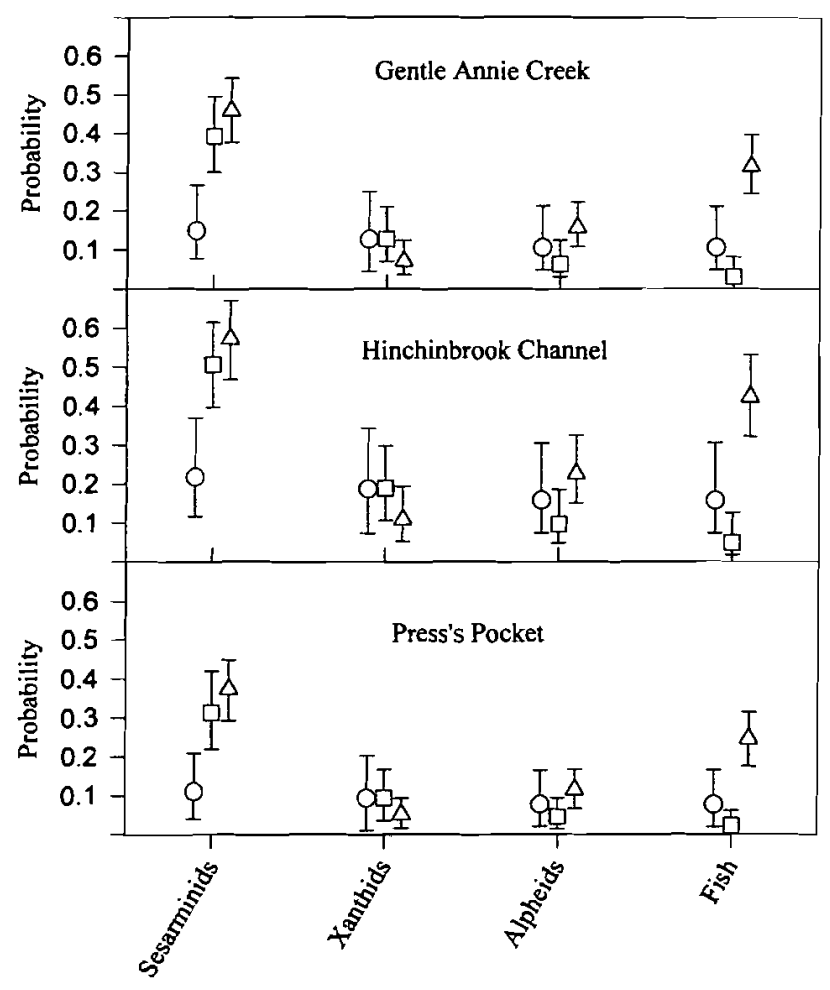

Fig. 3. Probabilities of finding sesarmid, xanthid, alpheid and fish prey in the guts of Epinephelus coioides (O), E. malabaricus $(\square)$ and Lutjanus argentimaculatus $(\Delta)$ from 3 locations. Data are fitted values from logistic regression $\pm 90 \%$ confidence intervals

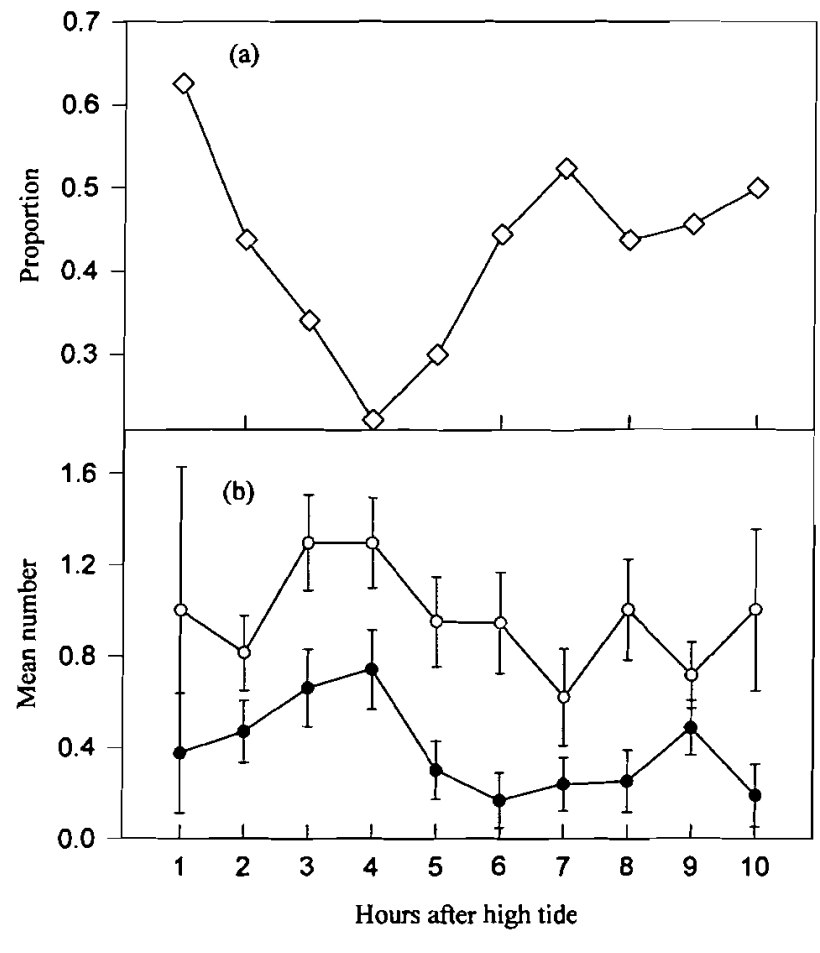

Fig. 4. Changes in (a) proportion of fish (Epinephelus coioides, E. malabaricus and Lutjanus argentimaculatus combined) with empty stomachs, and (b) mean number of sesarmid prey $(\bullet)$ and mean total prey numbers (o), with time after high tide. Error bars are $\pm 1 \mathrm{SE}$ sihama were benthic feeders, with bivalves the dominant prey items, but also including prey such as polychaetes, tunicates, gastropods, and micro-crustaceans (e.g. tanaids and amphipods) in their diets. The platycephalid Platycephalus fuscus and the carangids Caranx ignobilis and Scomberoides lysan fed mainly on fish and the sergestid shrimp Acetes australis, but also consumed penaeid shrimps. The diet of the carangid Caranx sexfasciatus was distinct from that of the other species in that $C$. sexfasciatus fed almost exclusively on $A$. australis with the only other dietary component being a small proportion of fish.

Mangrove stable isotope values (Fig. 6) were similar to those reported in other studies (e.g. Rezende et al. 1990, Primavera 1996). $\delta^{13} \mathrm{C}$ ranged from -28.60 to -24.28 and $\delta^{15} \mathrm{~N}$ from 0.04 to 6.45 . $\delta^{13} \mathrm{C}$ and $\delta^{15} \mathrm{~N}$ for benthic filamentous algae from mangrove for-

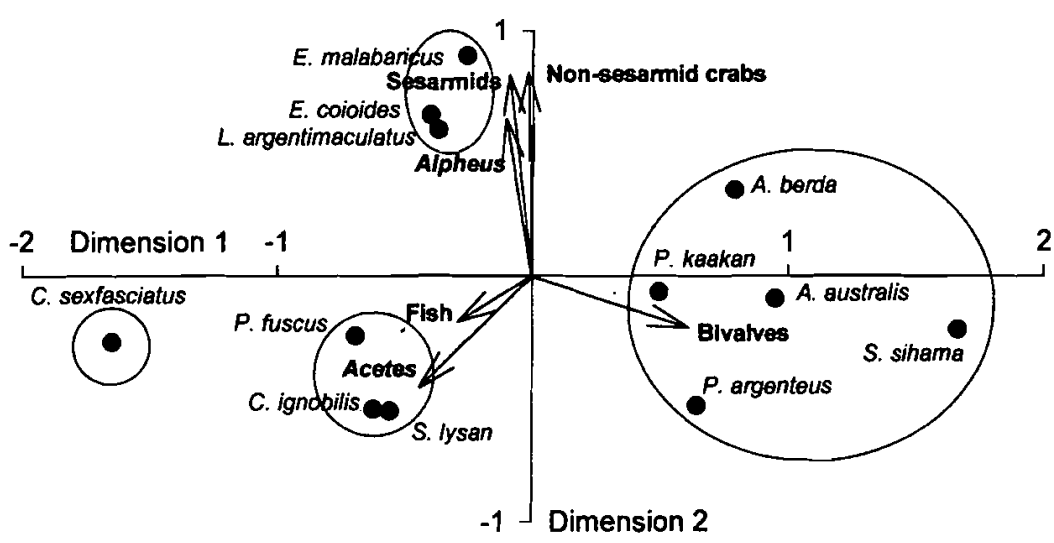

Fig. 5. Two-dimensional solution (Kruskal's STRESS1 $=0.054$ ) of a non-metric multidimensional scaling of the proportions of prey categories consumed by 12 species of fish. Filled circles indicate the relative positions of the fish species (italicized labels) in 2-dimensional space. Vectors indicate the directions of greatest increase of values for each of the prey categories (bold labels) in the 2 -dimensional space. Only prey categories with a squared multiple correlation coefficient of $>0.3$ are represented. Lengths of vectors are proportional to the squared multiple correlation coefficients, with a vector of unit length indicating a correlation coefficient of 1 . Open circles include fish species grouped together by a $K$-means $(K=4)$ cluster analysis 
est floors ranged from -25.32 to -24.09 and 4.10 to 4.75 respectively. Three samples, mainly comprising the chain-forming, planktonic diatom Bacteriastrum sp. $\left(\delta^{13} \mathrm{C}\right.$ : -27.9 to -25.8$)$ were collected but are not included in Fig. 6 because such a small sample size was unlikely to represent the stable isotope values of phytoplankton consumed over time by phytoplanktivores. A broad range of values of $\delta^{13} \mathrm{C}(-30$ to -18 , Fry \& Sherr 1984) have been reported for estuarine phytoplankton, and given the dynamic nature of planktonic systems, phytoplankton $\delta^{13} \mathrm{C}$ values are likely to fluctuate substantially over short periods of time as the composition of the phytoplankton community changes.

Epinephelus coioides, E. malabaricus and Lutjanus argentimaculatus were distinct from most other species of fish in terms of $\delta^{13} \mathrm{C}$ and $\delta^{15} \mathrm{~N}$ (Fig. 6). All had mean $\delta^{13} \mathrm{C}$ enriched by between about +0.75 and +2.0 , and mean $\delta^{15} \mathrm{~N}$ enriched by between +1.5 and +2.5 relative to the sesarmid crab Perisesarma messa. If an estimate of enrichment of about $+1 \delta^{13} \mathrm{C}$ and +2 to +3 $\delta^{15} \mathrm{~N}$ per trophic interaction is assumed (Peterson \& Fry 1987), the stable isotope values of most of this group, particularly $E$. malabaricus and $L$. argentimaculatus, are in the expected range for fish utilizing $P$. messa (or prey species with a similar diet) as a major food source. The mean $\delta^{13} \mathrm{C}$ of $E$. coioides was more enriched $\left(+2 \quad \delta^{13} \mathrm{C}\right)$ relative to $P$. messa than either $E$. malabaricus or $L$. argentimaculatus (both about +0.75 enriched). This is consistent with the stomach content analysis showing that $E$. coioides included a considerably smaller proportion of sesarmid crabs in its diet. The only species with similar values were Acanthopagrus berda and Toxotes chatareus, both of which also feed on sesarmid crabs (Table 1).

Mean $\delta^{13} \mathrm{C}$ values for Perisesarma messa were enriched by more than +4 compared to the overall mean $\delta^{13} \mathrm{C}$ of all mangroves and +1 enriched compared to the maximum value of mangroves $\delta^{13} \mathrm{C}$. Additionally, mean $\delta^{15} \mathrm{~N}$ for $P$. messa were +4 enriched over the mean of mangrove $\delta^{15} \mathrm{~N}$. In contrast, $\delta^{13} \mathrm{C}$ and $\delta^{15} \mathrm{~N}$ of $P$. messa were only enriched by +1.4 and +3.2 respectively compared to the filamentous benthic alga common in mangrove forests in the area. The alpheid shrimp Alpheus cf. malabaricus had $\delta^{13} \mathrm{C}$ and $\delta^{15} \mathrm{~N}$ values much closer to those expected for a mangrove leaf feeder (Fig. 6).

Other species of fish had $\delta^{13} \mathrm{C}$ and $\delta^{15} \mathrm{~N}$ values quite different from Epinephelus coioides, E. malabaricus, Lutjanus argentimaculatus, Acanthopagrus berda and Toxotes chatareus, suggesting different nutritional sources. A group including the benthic invertebrate feeders Pomadasys argenteus, $P$, kaakan and $A$, australis (Fig. 5, Table 1) had similar $\delta^{15} \mathrm{~N}$ values but was more greatly enriched in $\delta^{13} \mathrm{C}$, suggesting a different source of primary productivity. Even $P$. argenteus, the species closest in $\delta^{13} \mathrm{C}$ values to the sesarmid crab feeders, had a mean carbon isotopic ratio enriched enough compared to Perisesarma messa $(+2.9)$ to make it unlikely that $P$. messa, or animals with similar diets, contributed greatly to its nutrition. Stable isotopic ratios for the remaining species were even more enriched in $\delta^{13} \mathrm{C}$ and $\delta^{15} \mathrm{~N}$. These species include $\mathrm{Ca}$ ranx ignobilis, Platycephalus fuscus and Scomberoides lysan, identified as predators on fish and shrimps from gut content analysis (Fig. 5, Table 1).

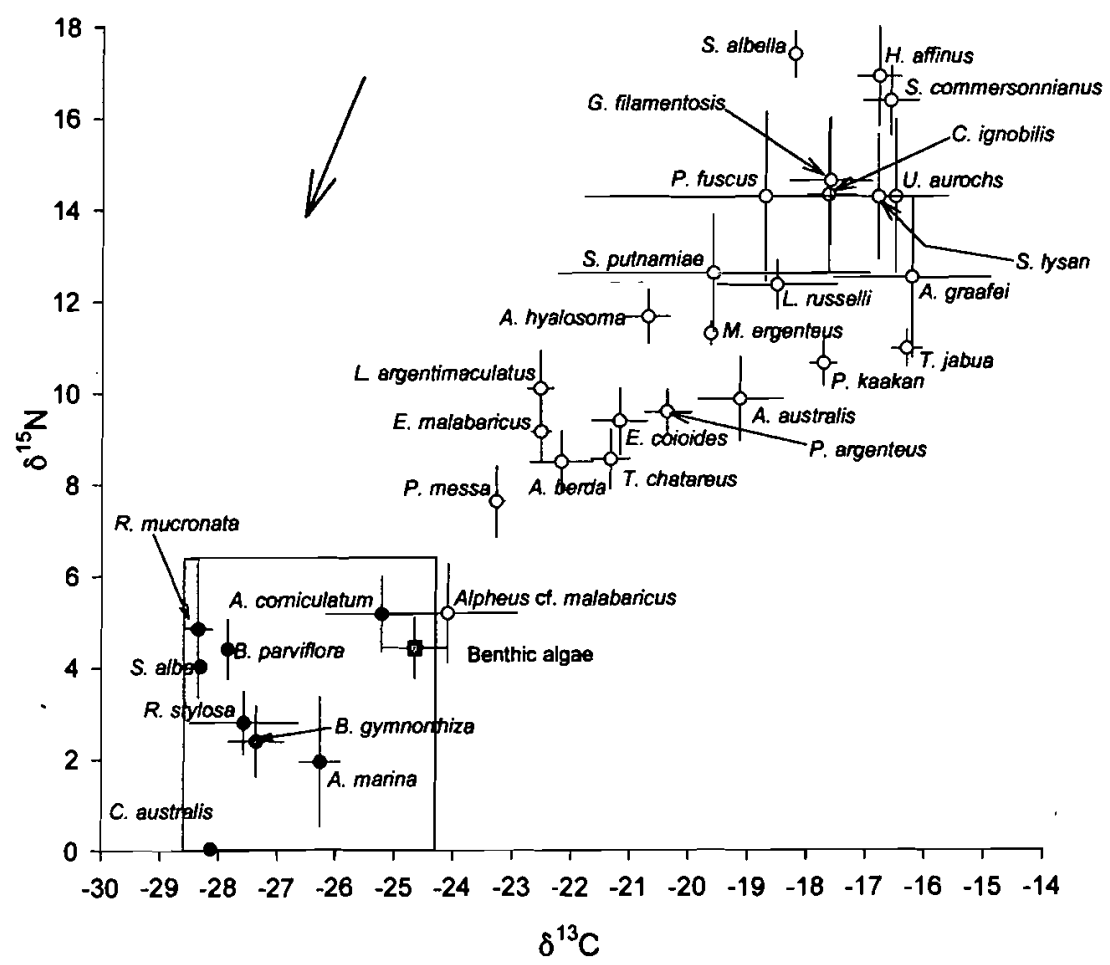

Fig. 6. Mean $\delta^{13} \mathrm{C}$ and $\delta^{15} \mathrm{~N}$ values for fish and crustaceans (o), and primary producers (mangroves $\bullet$, benthic algae $\square$ ). Error bars represent $\pm 1 \mathrm{SE}$. The large box indicates the range of values for mangroves. The large arrow indicates the relative position of 1 trophic level away from an organism, based on an enrichment of $+1 \delta^{13} \mathrm{C}$ and $+3 \delta^{15} \mathrm{~N}$ per trophic interaction, assuming an organism fed on only a single prey type. Sample sizes for plants are, mangroves: Aegiceras corniculatum 2, Avicennia marina 2, Bruguiera gymnorrhiza 2, Bruguiera parviflora 2, Ceriops australis 1, Rhizophora mucronata 2, Rhizophora stylosa 2, Sonneratia alba 1; benthic algae, unidentified filamentous chlorophytes 3 . Sample sizes of animals are given in Table 
Stable isotope values make it unlikely that species other than Epinephelus coioides, E. malabaricus, Lutjanus argentimaculatus, Acanthopagrus berda and Toxotes chatareus relied directly on mangrove primary productivity. Unfortunately, the ability of $\delta^{13} \mathrm{C}$ and $\delta^{15} \mathrm{~N}$ analyses to resolve the sources of primary productivity of these species is limited because of the overlapping $\delta^{13} \mathrm{C}$ and $\delta^{15} \mathrm{~N}$ values of the wide variety of primary producers present in tropical estuaries (mangroves, seagrass, benthic algae, phytoplankton).

\section{DISCUSSION}

Crabs of the brachyuran subfamily Sesarminae dominated the diets of Epinephelus coioides, E. malabaricus and Lutjanus argentimaculatus in the mangrove systems studied. The most commonly consumed sesarmid crabs were Perisesarma messa and P. semperi longicristatum, 2 leaf-feeding species that dominate many mangrove crab faunas in northeastern tropical Australia (Robertson \& Daniel 1989, Smith et al. 1991). Not only were sesarmids the most abundant prey in percentage occurrence and overall numbers, they were dominant in terms of biomass. Xanthid crabs, the only other common brachyuran family, were almost invariably small relative to sesarmids. Although fish were a relatively important prey category for $L$. argentimaculatus ( $32 \%$ of stomachs containing food), they were generally small (mean weight: $2.6 \pm 0.8 \mathrm{~g}$ ) compared to sesarmids (mean weight: $6.4 \pm 0.6 \mathrm{~g}$ ). The dominance of sesarmids is even more impressive when it is considered that many of the crabs that were categorized as Grapsidae or Brachyura, because they were too damaged to be classified to a lower taxonomic level, were probably sesarmids also. Not only were sesarmids consumed extensively, but $\delta^{13} \mathrm{C}$ and $\delta^{15} \mathrm{~N}$ values (Fig. 6) indicate that sesarmids, and/or prey with similar isotopic ratios (i.e. likely to have a similar trophic position as sesarmids), probably provided a large part of the carbon assimilated by these fishes.

The patterns of proportion of full stomachs, number of sesarmid prey and total prey numbers with time after high tide (Fig. 4) are consistent with an emphasis on feeding when the intertidal mangrove forests are inundated. The proportion of empty stomachs decreased and the proportion of sesarmids in the diets increased during the first part of the falling tide. This is what would be expected if the number of fish that had successfully captured prey increased with duration of time that the mangrove forest was accessible. During the low and early rising tide there was an increase in the proportion of empty stomachs and a decrease in the sesarmid content. This is as would be expected as prey caught during the previous high tide were passed from stomachs into intestines. During the late flood tide the proportion of empty stomachs stopped increasing and leveled out, indicating that many fish had captured fresh prey. Throughout the tidal cycle there was a consistent proportion of non-sesarmid prey over and above the sesarmid component. Thus, although there was an emphasis on feeding during the time when mangrove forests, and thus sesarmid prey, were available, a level of feeding on other prey continued throughout the tidal cycle.

The extent to which the dominance of sesarmids in the diet of Epinephelus coioides, E. malabaricus and Lutjanus argentimaculatus is applicable throughout the ranges of these species is unclear because previous studies have either been based on small sample sizes or not classified prey below the level of family or order. It does seem likely that sesarmids are important throughout much of eastern tropical Australia. Salini et al. (1990) reported that Brachyura was the dominant prey for both $E$. coioides (as $E$. suillus) $(\mathrm{n}=20)$ and $L$. argentimaculatus $(\mathbf{n}=11)$ from the Embley Estuary, a site separated from the site of the present study by some $1500 \mathrm{~km}$ of coastline. In the same area as the present study, Robertson \& Duke (1990) found that sesarmids comprised more than $30 \%$ by volume of the diet of $L$. argentimaculatus $(\mathrm{n}=10)$. Data from other areas are sparse. Morgans (1966) reported that $E$. coioides $(n=9)$ from estuaries in Africa fed on small fishes and shrimps, while van der Elst (1981) reported that the diet of E. malabaricus from the same area consisted primarily of fishes, with crayfish and crabs also being important.

The diets (Fig. 5, Table 1) and stable isotope profiles (Fig. 6) of Epinephelus coioides, E. malabaricus and Lutjanus argentimaculatus are quite different from most sympatric fishes. The archer fish Toxotes chatareus, usually thought of as an insectivore, had similar stable isotope values, and the stomachs of the 3 individuals sampled all contained small $(<7 \mathrm{~mm}$ carpace width) sesarmid crabs. Thus $T$. chatareus probably also feeds extensively on sesarmids or prey with similar stable isotope values. However, given the much smaller size of $T$. chatareus (maximum length $300 \mathrm{~mm}, 0.5 \mathrm{~kg}$ (Allen \& Swainston 1988) it is probably limited to feeding on small crabs and other prey items. The sparid Acanthopagrus berda, a medium-sized (reaching a little over $300 \mathrm{~mm}$ in the area sampled; Tobin et al. 1997) benthic omnivore, also had similar stable isotope values, and included a moderate number of sesarmids in its diet (present in $12 \%$ of fish). In contrast to E. coioides, E. malabaricus and $L$. argentimaculatus, because of their smaller sizes $T$. chatareus and $A$. berda are unlikely to be close to the top of estuarine food webs. Other large predators, such as Caranx ignobilis and Platycephalus fuscus, likely to be close to the top of 
estuarine food webs, had diets quite different (fish and penaeids) from $E$. coioides, E. malabaricus and $L$. argentimaculatus, and probably derived much of their carbon from different primary producers (enriched by an additional $+3 \delta^{13} \mathrm{C}$ ).

There was a general trend for stable isotope values of most fish, except Lutjanus argentimaculatus, Epinephelus malabaricus and perhaps Acanthopagrus berda, to fall below the 1:2 or 1:3 slope expected if there was a simple food chain leading from mangrove primary productivity (Fig. 6). Given this low. slope, the stable isotope values of these species probably reflect either quite different primary producers or mixing among primary producers, rather than simple trophic enrichment. This low slope is apparent for $E$. coioides, and probably reflects the derivation of carbon from a number of primary producers. This is consistent with the dietary data. Sesarmid crabs made a smaller contribution to the diet of $E$. coioides than to the diets of $L$. argentimaculatus or $E$. malabaricus. The enriched values of other species, such as the herbivore Hyporamphus affinis, the planktivore Sardinella albella, and pelagic predators like Scomberoieds lysan and Caranx ignobilis, probably reflect trophic webs based on primary producers other than mangroves.

Although the relative positions of $\delta^{13} \mathrm{C}$ and $\delta^{15} \mathrm{~N}$ of Epinephelus coioides, E. malabaricus, Lutjanus argentimaculatus and Perisesarma messa are consistent with the dietary analysis, stable isotope values for $P$. messa were more enriched relative to mangroves than would be expected of an animal deriving most of its organic carbon from mangrove productivity. This probably cannot be explained by $P$. messa feeding on leaves more decomposed than those analyzed here, because $\delta^{13} \mathrm{C}$ of mangrove leaves generally shows little change during decomposition and if anything $\delta^{15} \mathrm{~N}$ values become more depleted (Zieman et al. 1984). Thus the stable isotope data suggest that although $P$. messa consumes a large quantity of mangrove leaves (Robertson \& Daniel 1989) these may not be its only source of nutrition. This idea gains some support from the $\delta^{13} \mathrm{C}$ and $\delta^{15} \mathrm{~N}$ values for the alpheid shrimp Alpheus cf. malabaricus that are more typical of those expected of a mangrove litter feeder. $A$. cf. malabaricus is a mangrove crustacean that also collects and consumes mangrove leaves (J. Sheaves unpubl. data). Observations indicate that $P$. messa also spend a considerable amount of time picking from the mud surface, so may include other material in their diet. For example, the $\delta^{13} \mathrm{C}$ and $\delta^{15} \mathrm{~N}$ values of benthic filamentous algae suggest that this could be a food source of $P$. messa (Fig. 6). Other studies have also found unusually enriched $\delta^{13} \mathrm{C}$ values for different species of intertidal crabs (France 1998), and attributed this enrichment to selective assimilation following ingestion. Unambiguous conclu- sions about the diet of $P$. messa are not possible, however, because crab muscle tissue was analyzed so that values obtained would be consistent with the analysis of fish muscle. Muscle tissue tends to be enriched in $\delta^{13} \mathrm{C}$ compared to constituents such as lipid (e.g. Tieszen et al. 1983), so may not provide an accurate reflection of the relationship between mangrove carbon and $P$. messa tissue.

\section{Ecological implications}

Whatever the exact diet of the sesarmid crabs consumed by Epinephelus coioides, E. malabaricus and Lutjanus argentimaculatus, they still have low $\delta^{13} \mathrm{C}$ and $\delta^{15} \mathrm{~N}$, suggesting a trophic position close to primary productivity. In turn, the diet and $\delta^{13} \mathrm{C}$ and $\delta^{15} \mathrm{~N}$ of $E$. coioides, E. malabaricus and $L$. argentimaculatus imply that they derive much, or even most, of their nutrition from primary consumers. This suggests that food chains leading to these species are considerably shorter than might be expected for fish at or near the top of tropical estuarine food chains. This has a range of implications for the ecology of tropical mangrove systems in the Indo-Pacific region, in terms of food web complexity, food chain lengths, the retention and export of mangrove-derived productivity, and theories as to the value of mangrove systems as nursery grounds for fishes.

Recently it has been argued that food webs are usually more complex than suggested by conventional wisdom (Polis 1991, Hall \& Raffaelli 1993). An understanding of the pivotal role of sesarmid crabs in the functioning of Indo-Pacific mangrove ecosystems (Robertson 1991) has led to a reappraisal of early models of food webs for these systems (Fig. 7a). The addition of substantial, direct consumption of mangrove leaves by sesarmids, and the consequent retention of nutrients within the system, necessitates a more complex food web model (Robertson et al. 1992) (Fig. 7b). Extensive consumption of sesarmids by fishes, which would normally be considered higher carnivores, adds another layer of complexity (Fig. 7c). Because ecological relationships in mangrove systems are still incompletely understood, further study will probably uncover even greater complexity. Such complex pathways of energy flow profoundly affect web dynamics, spreading the effects of consumption and productivity throughout the web (Polis \& Strong 1996). At least in the IndoPacific, mangrove food webs can no longer be characterized as dominated by a simple uniserial chain. Instead there is an alternative pathway that, as well as directing nutrients back into the system, branches to lead directly to higher predators (Fig. 7c).

The bifurcation of this pathway has profound implications. The food chain leading from mangrove pro- 
ductivity to higher carnivores, which would normally involve an intermediate predator, is shortened by the direct feeding on leaf-eating sesarmids by lutjanids and serranids. This is important because a considerable amount of energy is lost in each trophic interaction, meaning that in most systems very little of the energy derived from primary productivity reaches top predators (Cousins 1996). Thus, compared with the detritus base system of Odum \& Heald (1975) (mangrove detritus $\rightarrow$ saprophytes $\rightarrow$ detritivores $\rightarrow$ lower consumer $\rightarrow$ higher consumer), a food chain with only 2 trophic interactions (mangrove leaves $\rightarrow$ crabs $\rightarrow$ fish) between primary producers and top predators allows a greater proportion of primary production to be channeled to the top of the food chain.

The channeling of primary productivity to the top of a shortened food chain is particularly important because of the life-history of Epinephelus coioides, $E$. malabaricus and Lutjanus argentimaculatus. Usually the consumption of sesarmid crabs by mangrove-asso-

(a)

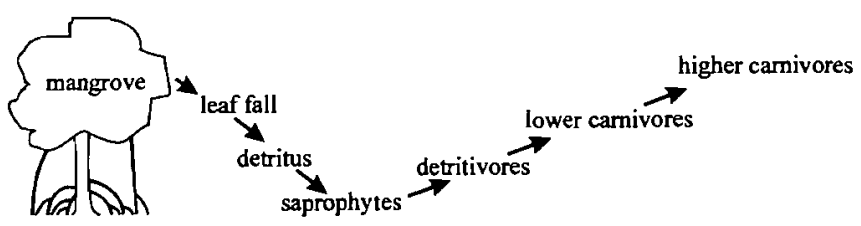

(b)

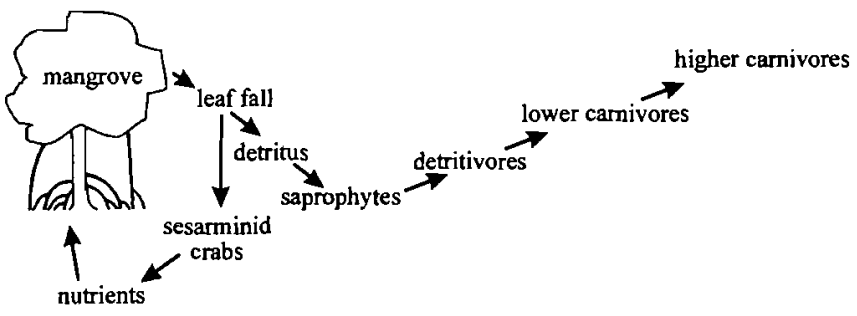

(c)

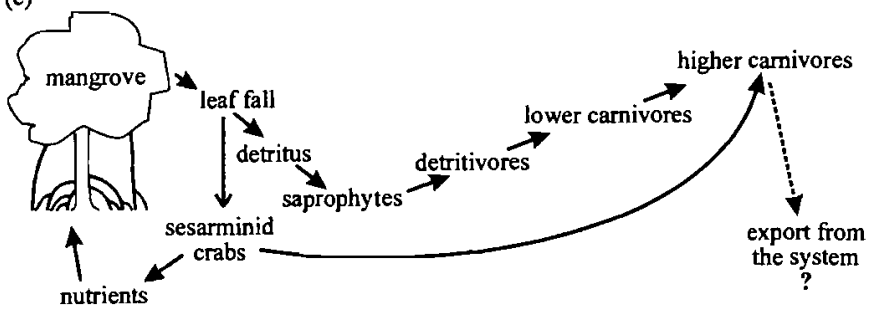

Fig. 7. Diagrammatic representations of 3 models of mangrove food webs. (a) A simple detritus base system (based on Odum \& Heald 1975), (b) a modified model including the influence of leaf eating sesarmid crabs, and (c) the modified model with the addition of direct consumption of sesarmid crabs by higher carnivores ciated fauna would mean that on the death of the predator energy derived from mangrove carbon would be reincorporated into the mangrove system through decomposition. Estuarine populations of $E$. coioides, $E$. malabaricus and $L$. argentimaculatus consist of juveniles that eventually migrate to adult habitats offshore (Sheaves 1995). Thus, rather than being retained within mangrove systems, a proportion of the mangrove productivity incorporated into sesarmid crab biomass and harvested by these fishes is exported from mangrove systems. Although estimates of energy and nutrient loss via this pathway are not available, the quantities of energy and nutrients exported from estuaries by biotic transport can be substantial. In estuaries of the Gulf of Mexico as much as 5 to $10 \%$ of total primary production is transported offshore during the migration of Brevoortia patronus from estuarine nursery grounds (Deegan 1993).

Assuming enrichment of about $+1 \delta^{13} \mathrm{C}$ per trophic level, most fishes other than the sesarmid crab feeders were between 4 and 8 steps away from mangrove productivity. Fish well away from mangrove productivity (enriched by $>+6 \delta^{13} \mathrm{C}$ over maximum mangrove values) included a herbivore (Hyporhamphus affinis), benthic feeders (e.g. Gerres filamentosus), planktivores (e.g. Sardinella albella) and predators (e.g. Caranx ignobilis) (Fig. 6). This suggests either very long food chains or that the food chains that many of these species participate in are largely based on primary producers other than mangroves. This is despite carbon fixed by mangroves usually providing the dominant contribution to food chains in riverine mangrove systems in the study area and other parts of the Indo-Pacific (Rodelli et al. 1984, Robertson et al. 1992). That many food chains appear to be based on alternative primary producers, despite the high and dominant productivity of mangroves, probably reflects the degree of recycling within mangrove forests. Thus the short food chain leading to predators like Epinephelus coioides, E. malabaricus and Lutjanus argentimaculatus, which export mangrove productivity when they migrate offshore, may be one of the few biological pathways channeling mangrove productivity out of these systems

The importance of the link between sesarmid crabs and Epinephelus coioides, E. malabaricus and Lut janus argentimaculatus is difficult to quantify because 2 important pieces of information are missing: accurate estimates of the abundance of sesarmid crabs and crab-eating fish, and how much prey a given predator consumes. Sesarmid crabs, such as Perisesarma messa, are known to consume a large proportion of annual mangrove leaf fall (Robertson 1986, Robertson et al. 1992), and are dominant components of Indo-Pacific mangrove forest fauna for sites where abundance estimates are available (Robertson 1986, Smith et al. 
1991). Unfortunately, estimates of their abundance are available for only a few sites, and estimates differ greatly between forest types (Robertson 1986), making extrapolation of abundances to other sites or larger scales of dubious validity. The situation for the fishes is worse because the snaggy habitats occupied by these species are difficult to sample quantitatively (Sheaves 1995). Even if reliable estimates of abundance were available, estimating the strength of links would still be problematic because determining exactly how many prey predators consume is a difficult task, to the extent that such information is rarely available for any system (Hall \& Raffaelli 1993). Despite these difficulties, leafeating sesarmid crabs are abundant and $E$. coioides, $E$. malabaricus and $L$. argentimaculatus are generally considered to be common in tropical Indo-Pacific estuaries (Blaber et al. 1989, Robertson \& Duke 1990, Sheaves 1992, 1995, 1996b), and make up a considerable proportion of recreational anglers' catches (ANSA 1991, Sheaves 1992). As a consequence the flow of energy from sesarmid crabs to these fishes is likely to be substantial. However, crab abundance often increases with increasing tidal elevation, probably reflecting high predation risk in frequently flooded areas (McIvor \& Smith III 1995). This suggests that predation on sesarmids by predators, like $L$. argentimaculatus, E. coioides and E. malabaricus, may be substantial in lower intertidal areas. It also suggests that any major 'short- circuiting' of mangrove food chains may be confined to these areas. Accurate estimates of abundance of both crab-eating fishes and sesarmid crabs, as well as estimates of consumption rates, are necessary before the importance of this link can be established.

The low rate of piscivory of estuarine phases of Lutjanus argentimaculatus, Epinephelus malabaricus and $E$. coioides has implications for theories relating to the nursery ground values of mangrove systems. It has been suggested that predatory fish are uncommon in tropical mangrove systems (Blaber 1980) and that this lack of predators, and consequent enhanced survivorship of small, juvenile fishes, may be one possible advantage of using tropical mangrove systems as nursery grounds (Robertson \& Blaber 1992). To some extent the apparent lack of predatory fish in tropical estuaries may result from a sampling artefact. Fish trap studies in complex habitats, inaccessible to other gears (Sheaves 1992, 1996a), suggest that large, habitat associated predators such as $L$. argentimaculatus, E. malabaricus and $E$. coioides may be much more common than the results of netting surveys would suggest. Furthermore, unlike predators such as carangids and carcharhinids that visit mangrove systems temporarily (Blaber et al. 1985), these serranids and lutjanids are present throughout the tidal cycle and throughout the year (Sheaves 1995). This line of argument would sug- gest that the 'few predator' theory may need to be revised. However, the present work indicates that fishes are minor components of the diets of $E$. coioides and $E$. malabaricus in estuaries. Furthermore, although $L$. argentimaculatus consume substantial numbers of fishes, rather than being juveniles of species from other habitats, these are mainly resident fishes such as gobiids. Thus, in a functional sense, the 'few predators' theory may still be tenable despite the large numbers of predatory serranids and lutjanids present in tropical mangrove systems. A further consequence is that if many of the large predators associated with complex habitats (fallen timber and mangrove prop-roots) do not target small juvenile fishes extensively, then these habitats may be more useful as shelters for juvenile fishes from open-water predators than it would appear at face value.

Acknowledgements. We thank all those who assisted in field collection for this project. We would also like to extend special thanks to P. Davie and J. Collins for their invaluable help in crab identification.

\section{LITERATURE CITED}

Allen GR, Swainston R (1988) The marine fishes of Northwestern Australia. Western Australian Museum, Perth

ANSA (Australian National Sportfishing Association) (1991) Sportfish Tagging Program, 1990/1991 Report. Australian National Sportfishing Association, Queensland, Brisbane

Blaber SJM (1980) Fish of the Trinity Inlet system of north Queensland with notes on the ecology of fish faunas of tropical Indo-Pacific estuaries. Aust J Mar Freshw Res 31: $137-146$

Blaber SJM, Young JW, Dunning MC (1985) Community structure and zoogeographic affinities of the coastal fishes of the Dampier region of north-western Australia. Aust J Mar Freshw Res 36:247-266

Blaber SJM, Brewer DT, Salini JP (1989) Species composition and biomasses of fishes in different habitats of a tropical northern Australian estuary: their occurrence in the adjoining sea and estuarine dependence. Estuar Coast Shelf Sci 29:509--531

Briand F (1983) Environmental control of food web structure. Ecology 64:253-263

Clarke KR (1993) Non-parametric multivariate analyses of changes in community structure. Aust J Ecol 18:117-143

Cohen JE, Briand F, Newman C (1986) A stochastic theory of community food webs. III. Predicted and observed lengths of food chains. Proc Roy Soc Lond 228:317-353

Collett D (1991) Modeling binary data. Chapman and Hall, New York

Cousins S (1987) The decline of the trophic level concept. TREE 2:312-316

Cousins S (1996) Food webs: from the Lindeman paradigm to a taxonomic general theory of ecology. In: Polis GA, Winemiller KO (eds) Food webs: integration of patterns and dynamics. Chapman and Hall, New York, p 243-251.

Davis TLO (1985) The food of barramundi, Lates calcarifer (Bloch), in coastal and inland waters of Van Diemen Gulf 
and the Gulf of Carpentaria, Australia. J Fish Biol 26: 669-682

Deegan LA (1993) Nutrient transport between estuaries and coastal marine ecosystems by fish migration. Can J Fish Aquat Sci 50:74-79

France R (1998) Estimating the assimilation of mangrove detritus by fiddler crabs in Laguna Joyuda, Puerto Rico, using dual stable isotopes. J Trop Ecol 14:413-425

Frusher SD, Giddins RL, Smith TJ Ill (1991) Distribution of mangrove sesarmid crabs (Crustacea: Brachyura) in northeastern Australia. Mem Queensl Mus 31:93

Fry B, Sherr EB (1984) $\delta^{13} \mathrm{C}$ measurements as indicators of carbon flow in marine and freshwater ecosystems. Contrib Mar Sci 27:13-47

Giddins RL, Lucas JS, Neilson MJ, Richards GN (1986) Feeding ecology of the mangrove crab Neosarmatium smithi (Crustacea: Decapoda: Sesarmidae). Mar Ecol Prog Ser 33:147-155

Hairston NG Jr, Hairston NG Sr (1997) Does food web complexity eliminate trophic-level dynamics? Am Nat 149 : 1001-1007

Hall SJ, Raffaelli DG (1993) Food webs: theory and reality. Adv Ecol Res 24:187-239

Kruskal JB, Wish M (1978) Multidimensional scaling. Sage Publications, Beverley Hills, CA

Lawton JH (1999) Are there general laws in ecology? Oikos 84:177-199

McIntosh RP (1985) The background of ecology: concept and theory. Cambridge University Press, Cambridge

McIvor CC, Smith TJ III (1995) Differences in the crab fauna of mangrove areas at a southwest Florida and a northeast Australian location: implications for leaf litter processing. Estuaries 18:591-597

Menge BA, Daley B, Wheeler PA (1996) Control of interaction strength in marine benthic communities. In: Polis GA, Winemiller KO (eds) Food webs: integration of patterns and dynamics. Chapman and Hall, New York, p 258-274

Minchin PR (1987) An evaluation of the relative robustness of techniques for ecological ordination. Vegetatio 69:89-107

Morgans JFC (1966) East African fishes of the Epinephelus tauvina complex, with a description of a new species. Annu Mag Nat Hist 8:257-271

Odum WE, Heald EJ (1975) The detritus-based food web of an estuarine mangrove community. In: Cronin LE (ed) Estuarine research. Academic Press, New York, p 265-286

Peterson BJ، Fry B (1987) Stable isotopes in ecosystem studies. Annu Rev Ecol Syst 18:293-320

Polis GA (1991) Complex trophic interactions in deserts: an empirical critique of food-web theory. Am Nat 138:123-155

Polis GA, Strong DR (1996) Food web complexity and community dynamics: Am Nat 145:813-846

Primavera JH (1996) Stable carbon and nitrogen isotope ratios of penaeid juveniles and primary producers in a riverine mangrove in Guimaras, Philippines. Bull Mar Sci 58: 675-683

Rezende CE, Lacerda LD, Ovalle ARC, Silva CAR, Martinelli LA (1990) Nature of POC transport in a mangrove ecosystem: a carbon stable isotope study. Estuar Coast Shelf Sci 30:641-645

Robertson AI (1986) Leaf-burying crabs: their influence on energy flow and export from mixed mangrove forests (Rhizophora spp.) in northeastern Australia. J Exp Mar Biol Ecol 102:237-248

Robertson AI (1991) Plant-animal interactions and the structure and function of mangrove forest ecosystems. Aust J Ecol 16:433-443

Robertson AI, Blaber SJM (1992) Plankton, epibenthos and fish communities. In: Robertson AI, Alongi DM (eds) Tropical mangrove ecosystems. American Geophysical Union, Washington, DC, p 173-224

Robertson AI, Daniel PA (1989) The influence of crabs on litter processing in high intertidal mangrove forests in tropical Australia. Oecologia 78:191-198

Robertson AI, Duke NC (1990) Recruitment, growth and residence time of fishes in a tropical Australian marine system. Estuar Coast Shelf Sci 31:723-743

Robertson AI, Alongi DM, Boto KG (1992) Food chains and carbon fluxes. In: Robertson Al, Alongi DM (eds) Tropical mangrove ecosystems. American Geophysical Union, Washington, DC, p 293-326

Rodelli MR, Gearing JN, Marshall N, Sasekumar A (1984) Stable isotope ratio as a tracer of mangrove carbon in Malaysian ecosystems. Oecologia 61:326-333

Salini JP, Blaber SJM, Brewer DT (1990) Diets of piscivorus fishes in a tropical Australian estuary, with special reference to predation on penaeid prawns. Mar Biol 105: 363-374

Shahrul AMS, Stuebing RB (1996) Diet, growth and movements of juvenile crocodiles Crocodylus porosus Schneider in the Klias River, Sabah, Malaysia. J Trop Ecol 12: 651-662

Sheaves MJ (1992) Patterns of distribution and abundance of fishes in different habitats of a mangrove-lined tropical estuary, as determined by fish trapping. Aust $\mathrm{J}$ Mar Freshw Res 43:1461-1479

Sheaves MJ (1995) Large lutjanid and serranid fishes in tropical estuaries: are they adults or juveniles? Mar Ecol Prog Ser 129:31-40

Sheaves MJ (1996a) The habitat specific distributions of some fishes in a tropical estuary. Mar Freshw Res 47:827-830

Sheaves MJ (1996b) Do spatial differences in the abundance of two serranid fishes in estuaries of tropical Australia reflect long-term salinity patterns? Mar Ecol Prog Ser 137: $39-49$

Smith TJ IIl, Chan HT, Mclvor CC, Robblee MB (1989) Comparison of seed predation in tropical tidal forests from three continents. Ecology 70:146-151

Smith TJ IlI, Boto KB, Frusher D, Giddins RL (1991) Keystone species and mangrove forest dynamics: the influence of burrowing by crabs on soil nutrient status and forest productivity. Estuar Coast Shelf Sci 33:419-432

Taylor JA (1979) The foods and feeding habits of subadult Crocodylus porosus Schneider in Northern Australia. Aust Wildlife Res 6:347-359

Tieszen LL, Boutton TW, Tesdahl KG, Slade NA (1983) Fractionation and turnover of stable carbon isotopes in animal tissues: implications for $\delta^{13} \mathrm{C}$ analysis of diet. Oecologia 57: 32-37

Tobin AJ, Sheaves MJ, Molony BW (1997) Evidence of protandrous hermaphroditism in the tropical sparid Acanthopagrus berda. J Fish Biol 50:22-33

van der Elst R (1981) A guide to the common sea fishes of southern Africa. Struik (Pty) Ltd., Cape Town

Webb GJW, Hollis GJ, Manolis SC (1991) Feeding, growth, and food conversion rates of wild juvenile saltwater crocodiles (Crocodylus porosus). J Herpetol 25:462-473

Winemiller KO, Polis GA (1996) Food webs: what can they tell us about the world? ln: Polis GA, Winemiller KO (eds) Food webs: integration of patterns and dynamics. Chapman and Hall, New York, p 1-22

Zieman JC, Macko SA, Mills AL (1984) Role of seagrasses and mangroves in estuarine food webs: temporal and spatial changes in stable isotope composition and amino acid content during decomposition. Bull Mar Sci 35:380-392 